\title{
INTRODUCTION The Politics of Empire in Post-Revolutionary France
}

\author{
Naomi J. Andrews \\ Santa Clara University \\ Jennifer E. Sessions \\ University of Iowa
}

The last two decades have seen a certain amount of handwringing among French historians, as the ending of the Cold War and the fading of bicentennial energies seemed to sap the urgency from historiographical debates about the French Revolution and call into question its defining place in the field's interpretive paradigms. ${ }^{* 1}$ The opening up of new archives and the effects of globalization have drawn scholarly attention toward the twentieth century, as well as toward France's manifold entanglements with the world beyond the boundaries of the famous "Hexagon." Colonial history has been one of the great beneficiaries of these historiographical shifts, as a wave of new scholarship has argued for the importance of the colonies and colonized peoples in shaping national identity and political cultures in modern France. If there is now a significant body of research showing the mutual constitution of republicanism and imperialism during the French Revolution and the Republics of the twentieth century, the field's emphasis on republican imperialism has nonetheless left important historical and interpretive lacunae in our understandings of the relationship between metropole and colonies under the nonrepublican regimes of the modern period. As Emmanuelle Saada recently remarked in the pages of this journal, "the attention to colonial phenomena is now generating a feeling of 'déjà-lu' with studies that describe the 'material' or 'symbolic' violence of the colonial order in often a repetitive manner, while underlining the 'colonial contradictions' of the Republic.... What we need 
now is more work that explores how imperial categories have informed definitions of nation-state and citizenship over the long-term."2

A revitalization of interest in the period following the French Revolution, which has occurred more quietly alongside the so-called colonial turn, offers one way forward. ${ }^{3}$ The years from the rise of Napoleon to the fall of his nephew, Napoleon III, were long seen as a singular struggle for democracy and social rights, in which embattled republican forces slowly fought toward their ultimate triumph in 1870. More recently, however, scholars have begun to consider the successive regimes of this period as imaginative, if ultimately unsuccessful, attempts to find a stable balance between absolute monarchy and popular republicanism. In the face of the political fragmentation, economic transformation, and cultural anxiety that characterize the present world of globalized neo-liberalism, this effort to shape the post-Revolutionary order has increasing resonance, while disappointment with the recent failures of French republicanism to cope with growing cultural diversity has prompted renewed interest in the paths not taken in the nineteenth century. ${ }^{4} \mathrm{New}$ histories highlight the political experimentation of a society rebuilding from decades of revolution and warfare. In the traumatic aftermath of the Revolution, Bonapartism, constitutional monarchism, liberalism, and socialism all proposed political alternatives to republicanism as the foundation of the French state, as well as new forms of citizenship and social subjectivity. ${ }^{5}$ Far from a simple way station on the path from 1789 to the triumph of the Republic in 1871, the middle decades of the nineteenth century constituted a period of ingenuity in which old and new were combined in novel ways by thinkers, politicians, artists, and ordinary citizens seeking "to restore a cohesive society and to find centripetal forces that might dampen the centrifugal impulses of dynamic transition." 6 New histories show that the process of reconstruction was both longer in duration and more thoroughgoing than previously recognized, linking political changes with such intimate matters as family, sentiment, and selfhood.

The articles in this issue emphasize that the post-Revolutionary "recovery" encompassed France's overseas colonies as well. In the wake of the abolition, then restoration, of slavery and political assimilation in the colonies during the Revolution and Napoleonic Empire, there ensued protracted struggles to redefine colonial systems of labor, race, citizenship, and nationhood. Until recently, scholars of French history interested in the "reciprocal influences and multidirectional flows between France and its diverse colonial possessions" largely overlooked this messy period of reconstruction. ${ }^{7}$ Historians of specific areas formerly colonized by France or of themes within colonial history had identified unifying local or regional chronologies spanning this period. Most notably, historians of the Atlantic World and of New World slavery began in the mid-1980s to recognize the century from the 1780s to 1880 s as the "age of abolition," in which slave revolts (themselves now usually included in a broader "age of Atlantic revolutions" against European domina- 
tion), Enlightenment humanitarianism, and structural economic changes combined to end African slavery in North America and the Caribbean. ${ }^{8}$ Historians of the Mediterranean, as well, have examined the influence of post-Revolutionary ideologies on French relations with Algeria, Egypt, and the Levant, charting the development of a technocratic, scientific, and cultural fascination with the "Orient." ${ }^{\prime 9}$ Nevertheless, dix-neuvièmistes have been slower than their colleagues of earlier and later periods to recognize the interpenetration of metropolitan and colonial histories.

This relative neglect is, in part, a reflection of historical realities: the French empire of the period was far smaller than the vast holdings of the Old Regime or the Third Republic, and colonial reconstruction lacked much of the drama that has drawn increasing scholarly attention to the period of the Revolution and decolonization. But the neglect also reflects a longstanding tyranny of republicanism in the historiography on France and its empire, as scholars interested in the linkages between metropole and colony have sought to understand the tensions between the egalitarian ideals of the Republic and the inequalities and violence of colonial rule in the modern period. It is political theorists interested in leading French liberal thinkers, especially Alexis de Tocqueville, who have begun to break this exclusive focus on republican imperialism. ${ }^{10}$ Important as their work is, however, it risks reproducing the focus on imperial "tensions" and "contradictions" within otherwise admirable ideologies, simply substituting nineteenth-century liberalism for eighteenth- or twentieth-century republicanism. The contributions to this special issue represent a new wave of scholarship that brings the insights of recent post-Revolutionary historiography to the process of colonial transition, when people across the empire saw in the uncertainties of the period opportunities and obligations to restructure colonial states, economies, and societies and to reimagine the relationship between France and its colonies. ${ }^{11}$

The trajectory of French colonialism between the First Empire and Third Republic was, like that of the metropole, one of collapse and rebirth. However, we must beware, as David Todd and others have recently argued, neither to exaggerate the Revolutionary break between the "first" and "second" colonial empires, nor to underestimate the importance of the intervening regimes' new initiatives overseas. ${ }^{12}$ The French overseas empire entered the post-Revolutionary period diminished in scope and strength after a half-century of dramatic losses, ${ }^{13}$ but French diplomats managed to negotiate the return of many former colonial territories at the Congress of Vienna, and energetic pressure from the government of Louis XVIII restored important Caribbean, West African, and Indian Ocean holdings to France. ${ }^{14}$ Thus despite significant territorial contraction during the eighteenth and early nineteenth centuries, France quickly re-emerged as a major player on the global imperial stage after 1815 .

The issue of slavery, both within the French empire and beyond, was of critical importance to the economic and political fate of the empire across the 
revolutionary and post-Revolutionary periods, generating recurrent conflicts within the French colonies as well as between France and other powers, especially the British. Forced by slave revolutionaries in the Antilles to enact the first emancipation of its chattel slaves by a European empire in 1794, the French Republic briefly extended metropolitan law to the colonies under the Constitution of 1795, which declared them an "integral part" of the nation, divided them into departments like the metropolitan territory, and reaffirmed the 1794 abolition decree. The Directory maintained this civic and political assimilation, although it was unevenly applied given the military situation in the colonies and increasingly "emptied" of substance. ${ }^{15}$ The Constitution of 1799 restored the differential legal regime whereby the colonies were "ruled by special laws," which would remain in place in virtually all French constitutions until the creation of the French Union after the Second World War. In 1802, Napoleon reinstated slavery in those territories where emancipation had been implemented. ${ }^{16}$ At the same time, a ban on the slave trade, initiated by Britain in 1807 and signed by France in 1817, then again in 1831, sparked clashes between the two powers over enforcement and led to labor shortages throughout the European plantation colonies. The passage of the British emancipation act of 1833 put further pressure on the French slave colonies and encouraged the revival of the French antislavery movement, although the "second" emancipation did not take place until after the February 1848 revolution.

The successive post-Revolutionary regimes simultaneously turned their ambitions to new areas and sought to restore French authority in the "vestiges" of the Old Regime empire. ${ }^{17}$ Building on the growth of exploration, missionary activity, and trade from the late eighteenth century, as well as rising international rivalries, they established new centers of French influence in the Maghreb, sub-Saharan Africa, the Indian Ocean, Oceania, south-east Asia, even Antarctica. France's global acquisitions from these years included: Algeria, invaded by the Bourbon king Charles X in 1830 and largely conquered in brutal fashion by Louis-Philippe's July Monarchy in the 1840s; Senegal, where governor Louis Faidherbe defeated powerful local rulers to establish French sovereignty and economic control during the Second Empire; the Marquesas islands, Tahiti, and New Caledonia in the Pacific, of which French naval officers took possession in 1843 and 1853, respectively, following a period of intensive scientific exploration and Catholic missionary activity; and Indochina, where French domination began with a naval expedition against the emperor of Annam and the occupation of Saigon in 1859, then expanded to include all of Cochinchina by 1867 and the establishment of a protectorate over Cambodia in 1863. Although the pace and scale of imperial conquest accelerated dramatically under the Third Republic, especially in Africa, the Restoration, July Monarchy, Second Republic, and Second Empire nonetheless all made critical additions to France's overseas holdings, while also negotiating the transition from slave to free and indentured labor during the middle decades of the century. 
Even as French domination expanded into regions usually associated with the second colonial empire, however, it did not constitute a distinct entity hermetically separated from either the first French empire or from other empires. The contributors to this special issue highlight the dense networks of intraimperial connection that linked individual French colonies (past and present) to one another and to France, creating new imperial formations that transcended traditional geographical and chronological boundaries. As their articles show, newly acquired territories in Africa and the Pacific were incorporated into existing French "networks of empire"18 and added new strands to the administrative, economic, migratory, cultural, discursive, and political webs that bound new colonies to old, and empire to metropole. People, ideas, and institutions not only traversed the upheavals of the revolutionary and Napoleonic periods, they also traveled between colonial territories. Thus, for example, the freedom suit of the falsely enslaved man Furcy, recounted by Sue Peabody, took him from the Ile Bourbon, restored to France in 1815, to Mauritius, which remained part of the British Empire, to Paris, and drew on the support of Louis Gilbert Boucher, a magistrate whose career and family connections spanned French imperial territory from Napoleonic Italy to Saint-Domingue, Corsica, and Paris, as well as Bourbon. Similarly, Allyson Delnore's analysis of French deportation practices details the "multidirectional" character of imperial penal policy, as political dissidents were moved between old colonies, newly conquered territories, and the metropole, depending on the needs of the state to maintain social order. Even within a single territory, as Miranda Spieler's study of French Guiana suggests, "new" and "old" empires collided in the realm of law, albeit not without conflict between local "old timers" who continued to define the colony by its Old Regime origins, and newcomers with a different vision of metropolitan authority over the colonial state. Captured contraband slaves likewise moved from the Old Regime world of the slave trade to a new legal regime where the trade was outlawed, while maroons ran away from French masters into British territory or areas that escaped French state control.

Political, social, legal, and imperial reconstruction worked out in uneven and complicated ways across the imperial space that was "France." Throughout this period, debates about and reforms to legal categories such as citizenship, freedom, enslavement, and emancipation created confusion and discontinuity, as well as a means by which the French state tried to consolidate its centralized control over both metropolitan and imperial spaces. The legal pluralism of the empire reflected the institutional and ideological heterogeneity of the time, but it also, in conjunction with the spatial "lumpiness" of state power, created opportunities for autonomy and negotiation for colonial residents, free and unfree. ${ }^{19}$ In the Furcy case, the free soil principle, which applied in the metropole, dictated that Furcy was born free; however, as Peabody demonstrates, the lumpiness of imperial power allowed colonists in the Indian Ocean to ignore metropolitan law and deny him his freedom. Like- 
wise, Spieler's article makes clear the extent to which the economic imperatives of the slavery regime could take a back seat-if temporarily-to a struggle for power between colonists and the imperial state. Metropolitan governors extended the authority of the colonial state into new regions of Guiana and into the private households of individual slave owners, infringing masters' claims to their human property and redefining slave abuse as a threat to public order and to the stability of slavery as an institution. As Jennifer Sessions's article on Algeria's place in the Revolution of 1848 shows, domestic transformations could trigger divergent, and even contradictory reforms in the empire. Thus, the Second Republic emancipated and enfranchised the remaining French slaves, while overseeing the political assimilation of Algeria's French colonists and the exclusion of both its indigenous people and immigrants from other European states. ${ }^{20}$

The post-Revolutionary state, which understood its sovereignty in imperial terms, sought to regulate its ostensibly free subjects within the metropole, as well, with similarly mixed results. Delnore's account of the penal system employed to remove malcontents from their sites of protest shows the extent to which the "center" was inextricably dependent on its multiple colonial "peripheries" in its efforts to impose its legal will even within continental France. In a period marked by indigenous resistance to the expanding French presence in Algeria and the growth and politicization of the "dangerous classes" in the metropole, deportation proved a useful tool for successive nineteenth-century regimes to both uproot insurgency and demonstrate state power both in the colonies and at home. In addition to removing dangerous individuals from restive situations, deportation demonstrated, both to political dissidents and to the public at large, the power and authority of the different French political regimes of the 1840s and 50s, whether monarchical, republican, or Bonapartist. Sessions's article reinforces these lessons in charting the Second Republic's repeated turns to Algeria in its search for stability in 1848 , first in importing military manpower to put down radical challenges in the June Days and then in creating new mechanisms for emigration to the North African colony to replace the National Workshops in French cities. These tactics backfired, however, as the deployment of colonial forces in France fueled new political opposition, and the Republic's Algerian colonization scheme collapsed under the weight of the new colonists' resistance to state regulations.

Although focused on different geographical regions, the articles presented here all explore the interrelations between colonial and metropolitan reconstructions in the first half of the nineteenth century. Whether looking across the Atlantic, the Mediterranean, or the Indian Ocean, the contributors emphasize that the restructuring of the French political and social order echoed throughout the empire and that colonial relationships were key to the process of rebuilding state and society in France. Highlighting the dual need to bring empire into the growing discussion about the post-Revolutionary period and 
the post-Revolutionary period into the now-robust conversation about French colonialism, they show us the critical role played by non-republican regimes in the formation of the modern French empire and the central place of the colonies in working out the Revolution's legacies in the nineteenth century.

Together, these historians suggest new ways forward in thinking about the relationship between metropolitan and colonial histories in modern France. On the one hand, attention to nineteenth-century imperial developments challenges traditional chronologies of the period. We see here significant continuities in state policy and personnel from the eighteenth century well into the nineteenth-including the free soil principle and policing of black bodies, conflicts between colonial councils and metropolitan-appointed bureaucrats, questions about the legitimacy of the slave trade and slavery, and a state apparatus that moved its subjects across the empire as a means of social control. At the same time, there are also significant moments of reinvention that propose alternative periodizations. The abolition of the transatlantic slave trade in 1817 emerges as far more important to "on the ground" dynamics considered here than the collapse of the Napoleonic Empire just two years before. Similarly, the overthrow of the Bourbons in 1830 had far less impact in the empire as a whole (and even arguably in France itself) than did the conquest of Algeria that predated it by a few weeks. On the other hand, in both the colonies and the metropole, struggles over citizenship, rights, and sovereignty carried through the decades between 1815 and 1870, when instability opened up possibilities for individuals to fight for rights within a wide range of ideological and institutional contexts. The "tensions" of French empire were not limited to the republican regimes that came before and after, and, indeed, as these essays show, focusing on "contradictions" overshadows the ways in which domestic and colonial developments were mutually constitutive rather than antagonistic. By rendering fruitless the search for contradictions within some ostensibly consistent ideological system, the pragmatism and hybridity of the post-Revolutionary regimes free us to consider other linkages between colonial and metropolitan histories.

Naomi J. Andrews is Associate Professor of History at Santa Clara University, where she teaches courses on modern France, gender, sexuality, citizenship, and imperialism. She is the author of Socialism's Muse: Gender and the Intellectual Landscape of French Romantic Socialism (2006). Her current work examines the relationship between early French socialism, slavery, and settler colonialism in the first half of the nineteenth century.

Jennifer E. Sessions is Associate Professor of History at the University of Iowa. Her research and teaching focus on modern French and European history, with an emphasis on French colonialism and cultural history. Her first book, By Sword and Plow: France and the Conquest of Algeria (2011), received the Mary Alice and Philip Boucher Prize from the French Colonial Historical Society. She 
is currently at work on a book about an uprising in the Algerian colonial village of Margueritte in 1901 and the public debate over the character of French settler colonialism that it sparked.

\section{Notes}

* The guest editors wish to thank Herrick Chapman, the anonymous reviewers, and the editorial staff at French Politics, Culture, and Society for their comments and support; the contributors to this special issue, Allyson Delnore, Sue Peabody, and Miranda Spieler; and the many colleagues who participated in discussions about post-Revolutionary empire that inspired this project, especially Andrew Aisenberg, Judith DeGroat, and Rebecca Hartkopf-Schloss.

1. Suzanne Desan, "What's after Political Culture? Recent French Revolutionary Historiography," French Historical Studies 23, 1 (2000): 163-65.

2. "More than a Turn? The 'Colonial' in French Studies," French Politics, Culture \& Society 32, 2 (2014): 34-35.

3. For the purposes of this special issue, we define the "post-Revolutionary period" from 1799-1870, although the articles here are primarily concerned with the period from the beginning of the Restoration through the first decade of the Second Empire.

4. Andrew Jainchill and Samuel Moyn, "French Democracy between Totalitarianism and Solidarity: Pierre Rosanvallon and Revisionist Historiography," The Journal of Modern History 76, 1 (2004): 107-54.

5. See, among others, Denise Davidson, France After Revolution (Cambridge, MA: Harvard University Press, 2007); Emmanuel Fureix, La France des larmes: Deuils politiques à l'âge romantique (1814-1840) (Seyssel: Champ Vallon, 2009); Jan Goldstein, The Post-Revolutionary Self: Politics and the Psyche in France, 1750-1850 (Cambridge, MA: Harvard University Press, 2005); Carol Harrison, The Bourgeois Citizen in Nineteenth-Century France: Gender, Sociability, and the Uses of Emulation (Oxford: Oxford University Press, 1999); Sudhir Hazareesingh, From Subject to Citizen: The Second Empire and the Emergence of Modern French Democracy (Princeton: Princeton University Press, 1998); Sudhir Hazareesingh, The Legend of Napoleon (London: Granta, 2004); Sudhir Hazareesingh, The Saint-Napoleon: Celebrations of Sovereignty in Nineteenth-Century France (Cambridge, MA: Harvard University Press, 2004); Jennifer Heuer, The Family and the Nation: Gender and Citizenship in Revolutionary France, 1789-1830 (Ithaca: Cornell University Press, 2005); Sarah Horowitz, Friendship and Politics in Post-Revolutionary France (University Park: The Pennsylvania State University Press, 2013); Andrew Jainchill, Rethinking Politics after the Terror: The Republican Origins of French Liberalism (Ithaca: Cornell University Press, 2008); Sheryl Kroen, Politics and Theater: The Crisis of Legitimacy in Restoration France (Berkeley: University of California Press, 2000); Jo Burr Margadant, "Gender, Vice, and the Political Imaginary in Postrevolutionary France," American Historical Review 104, 5 (1999): 1461-95; William Reddy, The Invisible Code: Honor and Sentiment in Postrevolutionary France, 1815-1848 (Berkeley: University of California Press, 1997) and The Navigation of Feeling: A Framework for the History of Emotions (Cambridge: Cam- 
bridge University Press, 2001); K. Steven Vincent, Benjamin Constant and the Birth of French Liberalism (New York: Palgrave Macmillan, 2011).

6. Cynthia Bouton, "Reconciliation, Hope, Trust, and Instability in July Monarchy France," French Historical Studies 35, 3 (2012), 542.

7. Alice Conklin and Julia Clancy-Smith, "Introduction: Writing Colonial Histories," French Historical Studies 27, 3 (2004), 500.

8. While most historians agree on the beginning of the Atlantic abolition movement, the end of the period depends on the precise date of legal abolition in different national contexts, with the last Latin American abolitions taking place in the 1880s. Robin Blackburn, The Overthrow of Colonial Slavery, 1776-1848 (London: Verso, 1988). On France, see Lawrence Jennings, French Anti-Slavery: The Movement for Abolition, 1802-1848 (Cambridge: Cambridge University Press, 2000); Marcel Dorigny, ed., Les Abolitions de l'esclavage: De L. F. Sonthonax à V. Schoelcher, 1793, 1794, 1848 (Saint-Denis: Presses universitaires de Vincennes; Paris: UNESCO, 1995), translated as The Abolitions of Slavery: From Léger Felicité Sonthonax to Victor Schoelcher, 1793, 1794, 1848 (New York: Berghahn Books; Paris: UNESCO, 2003). Literary scholars have made a marked contribution to this scholarship, particularly on slavery and the legacy of the Haitian Revolution. Christopher L. Miller, The French Atlantic Triangle (Durham, NC: Duke University Press, 2008); Joan Dayan, Haiti, History, and the Gods (Berkeley: University of California Press, 1998); Sibylle Fischer, Modernity Disavowed: Haiti and the Cultures of Slavery in the Age of Revolution (Durham, NC: Duke University Press, 2004).

9. Saint Simonianism has received particular attention. Osama Abi-Mershed, Apostles of Modernity: Saint-Simonians and the Civilizing Mission in Algeria (Stanford: Stanford University Press, 2010); Benjamin Brower, A Desert Named Peace: The Violence of France's Empire in the Algerian Sahara, 1844-1902 (New York: Columbia University Press, 2009); Ian Coller, Arab France: Islam and the Making of Modern Europe, 1798-1831 (Berkeley: University of California Press, 2011); Marcel Emérit, Les SaintSimoniens en Algérie (Paris: Belles Lettres, 1941); Patricia Lorcin, Imperial Identities: Stereotyping, Prejudice and Race in Colonial Algeria (London: I. B. Tauris, 1995), especially chap. 5; Pamela Pilbeam, Saint-Simonians in Nineteenth-Century France: From Free Love to Algeria (Houndsmills, Basingstoke: Palgrave Macmillan, 2014).

10. Cheryl Welch, "Colonial Violence and the Rhetoric of Evasion: Tocqueville on Algeria," Political Theory 31, 2 (2003): 235-64; Jennifer Pitts, A Turn to Empire: The Rise of Liberal Imperialism in Britain and France (Princeton: Princeton University Press, 2005). Older, but in this same vein, is Melvin Richter, "Tocqueville on Algeria," The Review of Politics 25, 3 (1963): 362-98.

11. Andrew Aisenberg, "The Facts of Social Organization in the Debate over North Africa, 1834-1852: Law, Government, Critique," French Historical Studies 35, 2 (2012): 351-80; Naomi J. Andrews, “'The Universal Alliance of all Peoples': Romantic Socialists, the Human Family, and the Defense of Empire During the July Monarchy, 1830-1848," French Historical Studies 34, 3 (2011): 473-502 and "Breaking the Ties: French Romantic Socialism and the Critique of Liberal Slave Emancipation," Journal of Modern History 85, 3 (2013): 489-527; Rebecca Hartkopf Schloss, Sweet Liberty: The Final Days of Slavery in Martinique (Philadelphia: University of Pennsylvania Press, 2009); Jennifer E. Sessions, By Sword and Plow: France and the Conquest of Algeria (Ithaca: Cornell University Press, 2011); Miranda Frances Spieler, Empire and Underworld: Captivity in French Guiana (Cambridge, MA: Harvard University Press, 2012).

12. David Todd, “A French Imperial Meridian, 1814-1870," Past \& Present 210, 1 (2011): 155-60.

13. Robert Aldrich, Greater France: A History of French Overseas Expansion (New York: St. Martin's Press, 1996), 20. The decades between 1756 and 1815 saw the cession of 
Quebec to Great Britain and Louisiana to Spain following defeat in the Seven Years' War (1756-1763). The loss of Saint Domingue in 1804 to former slaves encouraged the sale of Louisiana territory to the United States, further diminishing the French presence in the Americas. These losses were compounded by the seizure of virtually all other French colonies by the victorious Allies in the Napoleonic Wars (1799-1814).

14. Martinique and Guadeloupe in the Antilles, Guiana on the north shore of South America, Saint-Pierre and Miquelon in the north Atlantic, the Ile Bourbon (later Réunion) in the Indian Ocean, five comptoirs on the Indian subcontinent (Pondichéry, Mahé, Yanaon, Karikal, and Chandernagor), and the trading ports of Saint-Louis and Gorée in Senegal returned to French rule by 1817.

15. Constitution of 5 fructidor Year III (22 August 1795), in Les Constitutions de la France, ed. Jacques Godechot (Paris: Garnier-Flammarion, 1970), 102, 104. On the organic law of 12 nivôse Year VI regarding the constitutional status of the colonies and the implementation of departmental status, see Benoît Gainot, "La naissance des départements d'Outre-Mer. La loi du 1er janvier 1798," Revue des Mascareignes 1 (1999): 51-74, http://www.cresoi.fr/Revue-des-Mascareignes-no1-1999; Miranda Frances Spieler, "The Legal Structure of Colonial Rule during the French Revolution," The William and Mary Quarterly, $3^{\text {rd }}$ ser., 66, 2 (2009): 365-408.

16. Quote from Constitution of 22 frimaire Year VIII, in Godechot, Les Constitutions, 161.

17. Denise Bouche, Histoire de la colonisation française, vol. 2, Flux et reflux (1815-1962) (Paris: Fayard, 1991), 11. For basic narratives of French expansion in this period, on which we draw here, see Aldrich, Greater France, chap. 1 and 2; Bouche, Histoire de la colonisation française, chap. 1; Jean Meyer et al., Histoire de la France coloniale, vol. 1, Des origines à 1914 (Paris: Armand Colin, 1990).

18. Allyson Delnore borrows this phrase from Kerry Ward, Networks of Empire: Forced Migration in the Dutch East India Company (New York: Cambridge University Press, 2009).

19. On the "lumpiness" of power across imperial space, that is, its unevenness and inconsistency, see Frederick Cooper, Colonialism in Question: Theory, Knowledge, History (Berkeley: University of California Press, 2005), chap. 4.

20. In Algeria, representation in the National Assembly of the Second Republic was limited to French nationals, excluding both the indigenous population and immigrants from other European states. These distinctions were codified and reinforced by the sénatus-consulte of 1865 , which instituted a critical distinction between French citizens, European foreigners, and Muslim colonial subjects. See Laure Blévis, "Les avatars de la citoyenneté en Algérie coloniale ou les paradoxes d'une catégorisation," Droit et Société 48 (2001): 557-80; Gavin Murray Miller, "Imagining the Trans-Mediterranean Republic: Algeria, Republicanism, and the Ideological Origins of the French Imperial Nation-State, 1848-1870," French Historical Studies 37, 2 (2014): 303-30; Judith Surkis, "Propriété, polygamie et statut personnel en Algérie coloniale, 1830-1873," Revue d'histoire du XIXe siècle 41 (2010): 27-48. 